Journal of Economics and Behavioral Studies

Vol. 5, No. 8, pp. 505-510, Aug 2013 (ISSN: 2220-6140)

\title{
Personal Characteristics and Hedonic Shopping Orientation on Apparel Adult Shoppers' Repatronage Behavioral Intention
}

\author{
Yue-Teng Wong*, Syuhaily Osman \\ Universiti Putra Malaysia, Malaysia \\ *yueteng22@gmail.com
}

\begin{abstract}
A new direction of consumer centric marketing is now advocated to be included in the marketing module, yet there is a lack of shopping repatronage research based on a solid theoretical background pertinent to the issue. Based on the Reasoned Action Approach by Fishbein and Ajzen (2010), this study endeavors to examine the relationships between the personal characteristics, hedonic shopping orientation and repatronage behavioral intention. The structural equation modeling was used to analyze the causal relationships for the self-administrated data gathered from 569 apparel adult shoppers aged 30 to 60 years old. The refined hypothesized model was relatively good fitted. The personal characteristics of need for activity, impulsiveness, shopping confidence and susceptibility to influence were found significantly related to the repatronage behavioral intention. These relationships were fully mediated by the intervening variable of hedonic shopping orientation. The hypothesized model of hedonic mediating structural model explained $56 \%$ of the repatronage behavioral intention. The study advanced the understanding of the importance of hedonic shopping orientation as well as the personal characteristics in consumer-centric marketing.
\end{abstract}

Keywords: Personal Characteristics, Hedonic Shopping Orientation, Repatronage Behavioral Intention, Structural Equation Modeling, Mediating

\section{Introduction}

The mall market in Klang Valley as the main hub of shopping malls in Malaysia has reached to saturation point with the mushrooming of large-scale shopping centers. Currently, there is too much retail space chasing the same customers if judging by the number of malls. Since the past few years, the saturation condition has evidenced by the difficulty of the new shopping centers to fill up the occupancy upon opening (Mahalingam, 2011). Despite the difficulties, a reason for the malls continues to develop is due to the strong showing of shopping as the most popular and affordable forms of outing among Malaysian (Lee, 2013). This scenario is further supported by the statistic conducted by the Association for Shopping and Highrise Management, in which one in five Malaysians have spent the weekends in shopping malls (Price Waterhouse Coopers, 2005/2006). There was trail of research by Frank Small and Associates in reviewing that Malaysian adults (above 18 years old) spent quite a substantial amount of their leisure time (48\%) in shopping malls (Zafar, Ghingold \& Zainurin, 2007). Given that both potentials and constraints of the retail market, it is utmost important for the retailers to equip themselves with strong adaptation skills to compete with others as well as to correspond to the shifting shopping trends and fickle purchasing styles. To survive in the highly concentrated shopping industry, the retailers will need to rethink their business practices to grab the portion of spend from the new and existing shoppers who are actually displaying repatronage behavioral intention. In fact, a new direction of consumer centric marketing highlighting personal factor characteristics, which has not been popularized in most developing countries such as Malaysia, is now advocated to be included in the implementation strategy (Mburu, Mutua\& Massimo, 2002). Consumers have found to express their personality, social standing and intrinsic needs to change in the purchasing decisions (Kim \& Jin, 2002). In addition, there is a tendency among consumers to display the shopping orientations that are in consistent with their personality traits in mall consumption. The needs and desires of the consumers should be prioritized if the retailers intend to grab their segment of spend (Mburu et al., 2002). Hence, it is considered crucial to focus on the personal characteristics and shopping orientations of the shoppers in understanding the repatronage behavioral intention of the shoppers. 


\section{Literature Review}

Theoretical Background: The Reasoned Action Approach by Fishbein and Ajzen (2010) advocates that human's behavioral intentions are expected to comprehend in reasonable, consistent and often deliberate and spontaneous manner from the underlying cognitive foundation of beliefs about performing the behavior. The combination of attitude toward the behavior, perceived norm and perceived behavioral control are assumed in guiding the formation of behavioral intention and thus the readiness to perform the behavior. A person's attitude toward the behavior is largely determined by the positive or negative evaluation of the performance on the behavior. In addition, a person has perceived norm is reflected in the perceived social pressure of approving or disapproving of others to involve in a behavior. Perceived behavioral control could be viewed in the sense of self-efficacy derived from the personal and environment factors that influence the performance of the behavior. The personal characteristics, as the external feature of Reasoned Action Approach, could have influenced the attitude and the behavior of the individual (Cao \&Mokhtarian, 2005). Based on the Reasoned Action Approach, there was a string of external factors such as personality characteristic (Lin, 2006), brand loyalty (Choong, 1998; Gounaris \& Stathakopoulos, 2004), shopping motives (Eastlick\& Feinberg, 1999) and consumer expertise (Shwu-Ing, 2003) introduced in the marketing research. Again, based on Reasoned Action Approach, there was a positive relationship found particularly between the consumer attitudes and shopping orientation in the fashion industry (Kim \&Park, 2005).

The reasoned action framework suggests that in order to predict the behavior fully, the behavioral controls such as relevant skills and abilities should be taken into consideration. In the context of shopping behavior, the variable of shopping confidence, which deals with the ability to display a presentable self in both physical image and appearance, is regarded as the good predictor of shopping behavior (Shim \& Drake, 1988). The reasoned action paradigm also proposes that at times there are circumstances not completely under shoppers' command, but instead provoked by relevant others' expectancies. The interpersonal susceptibility influence refers to the readiness of a person to comply with the expectations of others in buying decisions (Bearden, Netemeyer\& Teel, 1989) is thus viewed as an important variable in influencing shopping behavior.The impulsiveness, which recognized as a personality-based consumer trait, could work as a component that facilitates the intention and the real action in the normative evaluation circumstance(Rook \& Fisher,1995). The social acceptability of impulsiveness in buying will affect the tendency of the shoppers to demonstrate the characteristic for a particular situation. Hagger, Chatzisarantis and Biddle (2002) have identified that the need for physical activity could be best represented by the cognitive theoretical framework in the pursuit of the reasoned action framework. In view of the influence of motivation being perceived as the element of the attitude component of reasoned action framework, hedonic shopping orientation as the subjective and experiential aspects of shopping is considered as an important motivation for consumption (Sproles\& Kendall, 1986). Grounded on the Reasoned Action Approach, this study investigated the constructs of personal characteristics hedonic shopping orientation and repatronage behavioral intention. Specifically, the purpose of this study was to validate the hypothesized relationships between the variables of personal characteristics (need for activity, impulsiveness, shopping confidence and susceptibility to influence), hedonic shopping orientation and repatronage behavioral intention among apparel adult shoppers in Malaysia. Moreover, this study also identified the feasible mediation effect of hedonic shopping orientation on the link of personal characteristics and repatronage behavioral intention.

\section{Methodology}

Research Design and Data Collection: The store-intercept quota sampling method was used to collect the responses from a sample of 600 adult apparel shoppers aged 30 to 60 years. The study focused solely on the apparel products due to the desirability to study marketplace with respect to specific product category coupled with the evidence of fashion clothing purchases as the most important purchase decision in the opinion of most Malaysian (Akir\& Othman, 2010). Those shoppers who were browsing for or buying apparel products in the apparel stores were chosen from the five shopping malls in Klang Valley (Malaysia): Sunway Pyramid, Berjaya Times Squares, Mid-Valley Megamall, The Mines and One-Utama. Data were collected using self-administrated questionnaire. A prior consent was gained before the respondents took part in the study. A 
final sample of 569 was employed in the analysis, with the omission of the non-usable responses of incompleteness and faulty in responses during the initial screening.

Measure and Validity: The validity of the model was assessed using confirmatory factory analysis in Structural Equation Modeling. The goodness-of-fit measures are important to determine how well the model best representing the data reflects the underlying theory $(\mathrm{Ho}, 2006)$. With the consideration to counter effect of multivariate, non-normality as well as to include at least one index from each of the index categories from absolute fit, incremental fit and parsimonious fit, the fit indices of Root Mean Squared Error Approximation (RMSEA), normed Chi-Square ( $\chi^{2} / \mathrm{df}$ ), Tucker-Lewis Index (TLI), Normed Fit Index (NFI) and Comparative Fit Index (CFI) were applied in the study (Hair, Black, Babin\& Anderson, 2010). In order to establish the model fit, the respective cutoff points of the indices have to be satisfied: RMSEA $\leq 0.08$ (MacCallum, Browne \& Sugawara, 1996), $\chi^{2} / \mathrm{df} \leq 5.0$ (Schumacker\& Lomax. 2010) and TLI, NFI, CFI $\geq 0.90$ (Blunch, 2008). The robustness of the model in the study were achieved using both the construct validity (standardized factor loadings and internal consistencies) and convergent validity (average variance extracted, AVE).

This dimension of need for activity was assessed based on three items developed by Buss (1988). The construct of impulsiveness was measured using a shortened version of impulsiveness established by Eysenck and Eysenck (1977). To identify the degree of agreement with shopping confidence, Shim and Drake's (1988) instrument consisted of six items was employed in the study. The study construct of interpersonal influence susceptibility was assessed based on Boush, Friestad and Rose's (1994) abbreviation version of instrument, in which two items were selected from the dimension of informational expression and another one item was chosen from the dimension of normative expression. The construct of hedonic shopping orientation was measured using the eight items selected items from Sproles and Kendall (1986). The items for the construct of need for activity, impulsiveness, shopping confidence, susceptibility to influence and hedonic shopping orientation were assessed based on a five-point scale anchored by the extreme of 'strongly disagree' (1) and 'strongly agree' (5). The eleven measurement items for repatronage behavioral intention were mainly adopted from the instruments developed by Bettencourt (1997), Campo, Gijsbrechts and Nisol (2000), De Wulf, Oderkerden-Schroder and Lacobucci (2001), Mehrabian and Russell (1974), Steenkamp and Baumgartner (1992), Syuhaily (2008) and Wakefield and Baker (1998). The assessments were done by rating on a seven-point scale from 'strongly disagree' (1) to 'strongly agree' (7) for the eleven items.

\section{Results}

The Maximum Likelihood Estimation (MLE) in AMOS version 20 was used as the estimation approach for the analysis of the full-fledged structural equation modeling in this study. The final mediation structural model in Figure 1 was found fitting the data relatively good with RMSEA $=0.058, \mathrm{NFI}=0.926, \mathrm{TLI}=0.944, \mathrm{CFI}=0.950$ and $\chi^{2} / \mathrm{df}=2.924$. Thus, this implied that the hypothesized model satisfactorily described the sample data. The hypothesized model of hedonic mediating structural model explained $56 \%$ of the repatronage behavioral intention which found higher than the direct model (39\%).Moreover, the construct validity was achieved in the study with standardized factor loadings for all the items ranging from 0.71 to 0.90 were significant at 0.001 levels. The internal consistencies for the variables were considered as adequate extending from 0.882 to 0.959 . The validity of the data was further substantiated by the absence of common method variance issue with the items explained $46 \%$ (less than $50 \%$ ) of the variance resided in the common factor. The AVE value varying from 0.670 to 0.776 satisfied the cut point of 0.5 has confirmed the convergent validity of the model.

As to identify the intervention effect of hedonic shopping orientation on the relationships between the predictor variables and repatronage behavioral intention, the test of indirect effect using bootstrapping was used. Apart from the advantage of being more susceptible to Type I error, bootstrapping approach was chosen owing to the presence of multivariate non-normality in the data. The bootstrap estimates were developed based on 5000 samples and $95 \%$ bias-corrected confidence intervals. The findings have indicated the results as in Table 1: 


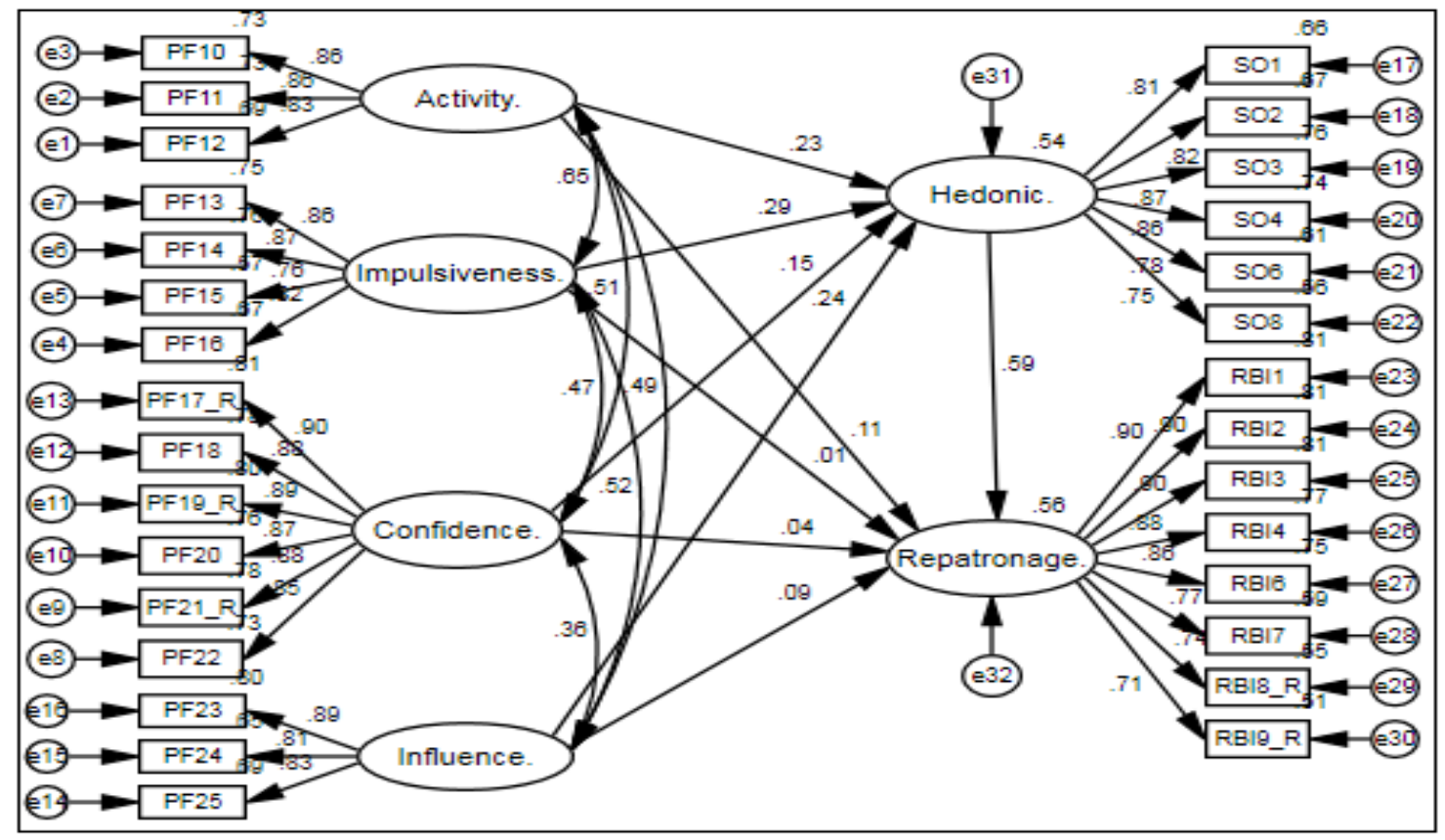

Figure 1: Full-fledged mediation structural model

Table 1: The effect of predictor variables on repatronage behavioral intentions through the mediation of hedonic shopping orientation

\begin{tabular}{|c|c|c|c|c|c|c|c|}
\hline $\begin{array}{l}\text { Independent } \\
\text { Variables }\end{array}$ & $\begin{array}{l}\text { Direct beta } \\
\text { without } \\
\text { mediation } \\
\end{array}$ & $p$ & $\begin{array}{l}\text { Direct beta } \\
\text { with } \\
\text { mediation }\end{array}$ & $p$ & $\begin{array}{l}\text { Indirect } \\
\text { beta }\end{array}$ & $p$ & $\begin{array}{l}\text { Mediation } \\
\text { Type observed }\end{array}$ \\
\hline Need for activity & 0.243 & $0.001^{* * *}$ & 0.109 & 0.115 & 0.134 & $0.001^{* * *}$ & Full Mediation \\
\hline Impulsiveness & 0.179 & $0.013^{* *}$ & 0.006 & 0.928 & 0.173 & $0.000^{* * *}$ & Full Mediation \\
\hline $\begin{array}{l}\text { Shopping } \\
\text { confidence }\end{array}$ & 0.132 & $0.009^{* *}$ & 0.042 & 0.336 & 0.090 & $0.002^{* * *}$ & Full Mediation \\
\hline $\begin{array}{l}\text { Susceptibility to } \\
\text { influence }\end{array}$ & 0.231 & $0.000^{* * *}$ & 0.089 & 0.102 & 0.143 & $0.000^{* * *}$ & Full Mediation \\
\hline
\end{tabular}

${ }^{* *}$ Significant at $p \leq 0.01,{ }^{* * *}$ Significant at $p \leq 0.0001$

\section{Discussion and Conclusion}

The analysis of structural equation modeling evidenced that the hypothesized model was a full mediation model. The personal characteristics of need for activity, impulsiveness, shopping confidence and susceptibility to influence were found inducing the repatronage behavioral intention. With the interference of the intermediate variable of hedonic shopping orientation, the total effect of the process by which the predictor variables influence repatronage behavioral intention has entirely being explained. Practically, the full mediation effect could be regarded as an indication of the significance of the hedonic shopping orientation in explaining the total effect. Therefore, it is noted that the influences of personal characteristics toward repatronage behavioral intention are formed within the context of hedonic shopping orientation. The findings of the study were in conformity to the assertion of Reasoned Action Approach, in which the predictors of intentions can undertake varying emphases in revealing that the intention to perform a behavior is built on a specific combination of attitudinal, normative and control concerns. Even though personal characteristics have intrinsic nature in basis, hedonic shopping orientation may perhaps be important in retaining or 
changing the outcomes. In overall, it can be concluded that the understanding of the relations between personal characteristics and repatronage behavioral intention could be in more depth with the consideration of the impact of hedonic shopping orientation. The findings could have implications for theory building as they revealed the plausibility of additional mechanisms. Nevertheless, the contentions of full mediation can gratuitously restrict theory development, as when there might be other mediating paths.

\section{References}

Akir, 0. \& Othman, M. D. (2010). Consumers' shopping behavior pattern on selected consumer goods: Empirical evidence from Malaysian consumers. International Review of Business Research Paper, 6(4), 279-294.

Bearden, W. O., Netemeyer, R. \& Teel, J. E. (1989).Measurement of consumer susceptibility to interpersonal influence. Journal of Consumer Research, 15, 473-481.

Bettencourt, L. A. (1997). Customer voluntary performance: Customers as partners in service delivery. Journal of Retailing, 73(3), 383-406.

Blunch, N. J. (2008). Introduction to Structural Equation Modeling using SPSS and AMOS. Thousand Oaks, CA: Sage Publications Ltd.

Boush, D. M., Friestad, M. \& Rose, G. M. (1994).Adolescent skepticism toward TV advertising and knowledge of advertiser tactics. Journal of Consumer Research, 21(1), 165-175.

Buss, A. H. (1988). Personality: Evolutionary Heritage and Human Distinctiveness. Hillsdale. N.J.: Lawrence Erlbaum Associates.

Campo, K., Gijsbrechts, E. \& Nisol, P. (2000).Towards a Theory-Based Measure of Purchase Variation.Academy of Marketing Science Review.

Cao, X. Y. \& Mokhtarian, P. L. (2005). The Intended and Actual Adoption of Online Purchasing: A Brief Review of Recent Literature. Institute of Transportation Studies, Working Paper Series. Institute of Transportation Studies, UC Davis.

Choong, L. H. (1998). The theory of reasoned action applied to brand loyalty. Journal of Product and Brand Management, 7(1), 51-61.

De Wulf, K., Odekerken-Schroder, G. \& Lacobucci, D. (2001). Investments in consumer relationships: A crosscountry and cross industry exploration. Journal of Marketing, 65(4), 18-51.

Eastlick, M. A. \& Feinberg, R. A. (1999). Shopping motives for mail catalog shopping. Journal of Business Research, 45(3), 281-290.

Eysenck, S. B. \& Eysenck, H. J. (1977).The place of impulsiveness in a dimensional system of personality description. British Journal of Clinical Psychology, 16, 57-68.

Fishbein, M. \& Ajzen, I. (2010). Predicting and Changing Behavior: The Reasoned Action Approach. New York: Psychology Press, Taylor \& Francis Group.

Gounaris, S. \& Stathakopoulos, V. (2004). Antecedents and consequences of brand loyalty: An empirical study. Journal of Brand Management, 11, 283-306.

Hagger, M. S., Chatzisarantis, N. L. D. \& Biddle, S. J. H. (2002). A meta-analytic review of the theories of reasoned action and planned behavior in physical activity: Predictive validity and the contribution of additional variables. Journal of Sport and Exercise Psychology, 24 (1), 3-32.

Hair, J. F., Black, W. C., Babin, B. J. \& Anderson, R. E. (2010).Multivariate Data Analysis.(7th ed), Upper Saddle River, NJ: Pearson Prentice Hall.

Ho, R. (2006). A Handbook of Univariate and Multivariate Data Analysis and Interpretation with SPSS. Francis and Taylor Group: LLC.

Kim, O. K. \& Jin, B. (2002).Korean consumers' patronage of discount.stores: Domestic vs. multinational discount store shoppers' profiles. The Journal of Consumer Marketing, 18(3), 236-255.

Kim, J. \& Park, J. (2005). A consumer shopping channel extension model: Attitude shift toward the online retailer.Journal of Fashion Marketing and Management, 9(1), 106-121.

Lee, L. (2013). Yen Global: Malaysia's Retail Sector Probably Grew 5\%. Star Biz Week, Retrieved January 2, 2013 from http://biz.thestar.com.my/news/story.asp?file=/2013/1/2/business

Lin, W. B. (2006). Correlation between personality characteristics, situations of service failure, customer relation strength and remedial recovery strategy. Services Marketing Quarterly, 28(1), 55-88. 
MacCallum, R. C., Browne, M. W. \& Sugawara, H. M. (1996).Power Analysis and Determination of Sample Size for Covariance Structure Modeling. Psychological Methods, 1, 130-149.

Mahalingam, E. (2011). Whither Retail Space? There's An Oversupply of Retail Space throughout the Country. Star Biz Week, pp.22.

Mburu, P. T., Mutua. K. \& Massimo, S. K. (2002). A study of apparel buyer motivations. Journal of Applied Science, 2(6), 673-681.

Mehrabian, A. \& Russell, J. A. (1974).An Approach to Environmental Psychology. Cambridge, MA: Massachusetts Institute of Technology.

Price Waterhouse Coopers. (2005/2006). From Beijing to Budapest-Winning Brands, Winning Formats.(4thed.). Retrieved September 5, 2011 from http://www.pwc.com/en_GX/gx/retailconsumer/pdf/malaysia.pdf

Rook, D. W. \& Fisher, R. J. (1995). Normative influences on impulsive buying behavior. Journal of Consumer Research, 22, 305-313.

Schumacker, R. \& Lomax, R. (2010).A Beginner's Guide to Structural Equation Modeling. (3rd ed). Mahwah, N.J.: Lawrence Erlbaum Associates.

Shim, S. \& Drake, M. F. (1988). Apparel selection by employed women: A typology of information search patterns. Clothing and Textiles Research Journal, 6, 1-9.

Shwu-Ing, W. (2003).The relationship between consumer characteristics and attitude toward online shopping. Marketing Intelligence and Planning, 21, 37-44.

Sproles, G. B. \& Kendall, E. L. (1986). A methodology for profiling consumers' decision-making styles. Journal of Consumer Affairs, 20(2), 267-279.

Steenkamp, J. B. \& Baumgartner, H. (1992).Assessing measurement invariance in cross-national research. Journal of Consumer Research, 25, 78-90.

Syuhaily, O. (2008). Mood as a Mediating Variable between Store Atmospheric and In-Store Behaviour: A Study of Young and Old Consumers. Universiti Malaya (unpublished thesis).

Wakefield, K. L. \& Baker, J. (1998). Excitement at the mall: Determinants and effects on shopping response. Journal of Retailing, 74(4), 515-539.

Zafar, U. M., Ghingold, M. \& Zainurin, D. (2007). Malaysian shopping mall behavior: An exploratory study. Asia Pacific Journal of Marketing, 19(4), 331-348. 